\title{
The Future of Traditional Customary Uses of Wildlife in Modern Africa: A Case Study of Kenya and Botswana
}

\author{
Nixon Sifuna \\ School of Law, Moi University, Eldoret, Kenya \\ Email: nsifuna@yahoo.com
}

Received October 26 ${ }^{\text {th }}$, 2011; revised November 29 $9^{\text {th }}$, 2011; accepted December 27 ${ }^{\text {th }}, 2011$

\begin{abstract}
This paper discusses the future of traditional customary uses of wildlife in Africa. The continent's wildlife is as old as humanity or perhaps even older. Indeed wildlife has through the ages remained a valuable resource for the African society; both in its traditional setting and in its modern form. While wildlife has some conventional and universal uses to society, there are some uses that are anthropologically unique to the African traditional way of life and therefore warrant special consideration. Such uses, for instance, manifest the inextricable attachment of the African peoples to the continent's wildlife. Indeed there is a crucial link between wildlife and many traditional African cultural values and practices. One way in which these values manifest themselves is through the traditional customary uses of wildlife by the people. These uses are consumptive in nature and largely geared towards meeting the basic needs of humankind such as food, health and clothing. Research for this study was conducted in the Laikipia region of Kenya and the Okavango Delta region of Botswana. Information was obtained by the use of semistructured interviews, self-administered questionnaires, focus group discussions, and literature survey. The respondents included government officials, NGOs, experts as well as local communities. A total of 44 respondents were interviewed from each country, comprising households from the local communities within wildlife areas, senior ranking government officials, leaders of NGOs that actually work on wildlife issues, experts in natural resource management as well as eminent scholars in environmental and natural resources law and policy. The study established that these traditional uses continue to be either relegated by modern (or rather Western) way of life especially Christianity or restricted by the laws that are fashioned on American and European perceptions. This state of affairs has been largely engendered by western values as a result of colonialism, modern lifestyles as well as religious transformation from traditional African religions to Islam, Christianity and other present day religions. Admittedly, traditional wildlife uses are not necessarily undesirable and there is need for them to be recognized and promoted by the existing policies and laws. The paper recommends that African governments should, through their policies and laws, recognize and promote these traditional uses of wildlife. This is one way of ensuring that wildlife contributes to the day to day life of the people. It is only when this is achieved that the people of this needy continent of Africa will begin to appreciate the value of wildlife as a valuable resource to the present and future generations. Notably, the value of wildlife in western societies differs radically from its value in the traditional African context. While in western societies the importance of wildlife is perceived from its intrinsic value, in the traditional African context it is perceived from its direct uses-consumptive uses.
\end{abstract}

Keywords: Wildlife Values; Traditional Customary Wildlife Uses; Socio-Cultural Uses; Totems; Traditional African Values

\section{Introduction}

The African continent has an abundant and richly varied wildlife endowment surpassing most places on earth. This endowment is a natural heritage for the present and future generations, with several beneficial uses of the wildlife resources. It has some animals that are rare and not found in many places in the world. The Choice of Kenya and Botswana is appropriate. First, it presents a comparison between a country in which consumptive uses of wildlife are permitted (i.e. Botswana) and a country in which only non-consumptive uses of wildlife are permitted.

Secondly, the respective land area of both these two countries is about the same; and both have some of the most abundant and most diversified wildlife estates in Africa with many species of wild animals. Admittedly, there is a historical relationship between the African people and wildlife, a relationship that is resilient and one that has existed from time immemorial and through the generations to the present and hopefully to posterity.

The Botswana Government in the Tenth National Development Plan of 2010 lists the benefits derived from wildlife as cultural, socio-economic and biological integrity; creation of employment opportunities; enhancing environmental stability; providing aesthetic, scientific, nutritional and educational value; and promoting tourism. The plan further reports that "Botswana's tourism industry is currently overwhelmingly dependent on wildlife.” The Kenya government in its Wildlife Policy of 2007 states that "Kenya's wildlife is one of the richest and most diversified in Africa with several of its protected areas and wetlands being internationally recognized and protected as World Heritage Sites, Ramsar sites and Man and Biosphere Reserves”. 
While wildlife has a wide array of benefits, economic benefits in many cases are perhaps the most emphasized. Wildlife plays a major role in the economy in more than one way. Principally, wildlife is an economic sector in its own right in terms of providing employment and contributing to the national income through earnings from wildlife tourism. In terms of employment, the wildlife sector in Kenya and Botswana provides employment to many who are employed either in state and governmental agencies or in other wildlife support agencies such as hotels, tour companies and beach resorts associated with the sector. In Kenya, the tourist sector accounts for about 400,000 jobs in the formal sector and over nine percent of the country's total wage bill (GOK Official Website). In Botswana it accounts for at least 10,000 jobs (GOB Official Website). Notably, in both countries, the most notable economic benefit of wildlife is its contribution to the economy in terms of earnings from wildlife tourism. An appreciable part of tourism earnings in these countries are attributable directly or indirectly to wildlife.

Earnings from tourism usually run into billions in direct income and foreign exchange, thereby contributing a large share of the national income. Tourism earned Kenya 56.2 and 65.4 billion Kenya shillings in 2006 and 2007, respectively (GOK Official Website). The Kenya Government in the Tenth National Development Plan estimates that approximately 70 percent of the total tourism earnings can be attributed directly to wildlife. Tourism is also Botswana's second largest foreign exchange earner after diamonds, estimated to contribute about BP 495 million which is approximately 4.5 per cent of the country's Gross Domestic Product (GOB Official Website). The Government of Botswana in the Ninth and Tenth National Development Plan notes that "Botswana's tourism industry is currently overwhelmingly dependent on wildlife.” Government of Botswana in a report, (GOB, Wildlife Statistics, 2005), reports that "wildlife tourists mostly come to the country for trophy hunting, wildlife photography and viewing." Wildlife tourists are tourists who come to a country because of its wildlife. Interestingly however, contrary to the fact that wildlife earns these two countries millions of dollars through tourism, most of the people in most villages attribute their poverty to wildlife (Sifuna, 2009). This is largely because large tracts of land are reserved to wild animals as wildlife protected areas. Secondly, is the harm that wild animals cause to society when they attack people or destroy their crops, livestock and other material property. Thirdly, that government authorities tend to alienate wildlife from the people and deny them the historical benefits they have enjoyed from wildlife through the ages.

Apart from its economic value, wildlife has from time immemorial been a valuable natural resource in Africa, with several other traditional beneficial uses to society. This does not in any way mean that wildlife can only exist with reference to its uses to human kind. Indeed it has a right to exist in itself without such reference. Nevertheless, there are three major traditional uses of wild animals in Africa, namely, uses for sociocultural purposes, nutrition and folk medicine. These are what are referred to in this paper as "traditional customary uses" of the resource. With the advent of the modern society there has been a paradigm shift from the traditional customary approach that emphasizes use to a western approach that emphasizes value. Accordingly the contemporary value of wildlife includes economic value; ecological value; medicinal value; educational and scientific value; and recreational value. This seems to rele- gate to the backyard the traditional customary uses of wildlife, which has largely upset the symbiotic relationship that has always existed between Africans and their wildlife.

Before the arrival of the colonialists, the indigenous African communities co-existed with wild animals, utilizing them as they needed, and in accordance only with African customary practices and values (Muriuki, 1996). These communities hunted wild animals for food and other uses such as clothing, bedding and cultural purposes. Many ethnic groups, however, had totem animals-animals believed to be sacred and which were therefore left unharmed or which could only be utilized for prayers or medicinal purposes. Generally, there were traditional customs, rules, taboos, beliefs and practices of the various ethnic groups relating to wildlife (ODA, 1996). With the advent of imperialism, things changed dramatically as all over a sudden the colonial governments imposed stiff laws on wildlife utilization, mainly on hunting and wildlife products. Takirambudde has observed that colonialism in Africa created "a new legal order to replace the traditional structures and ideology” (Tarakimbudde, 1988).

The paper examines the traditional African customary uses of wildlife, with Kenya and Botswana as the case studies. It is divided into six parts. Part one is an introduction that introduces the subject of this work as well as the major concepts and issues involved. Part two discusses the traditional customary uses of wildlife in Africa in terms of its uses for socio-cultural uses, nutritional uses as well as its uses in folk medicine. This part is meant to highlight how Africans have traditionally utilized their wildlife resources as a way of setting the stage to compare these uses with the contemporary uses of wildlife in the modern society that has been influenced by western values as well as foreign religions. Part three discusses the uses of wildlife in the latter context. Part four projects the future of African customary uses of wildlife based on the existing trends and also makes recommendations on how these uses can be preserved and promoted in order to sustain the cultural link between the indigenous inhabitants of Africa and the continent's wildlife resources. It also makes conclusions that tie up the issues discussed in the paper.

\section{Traditional African Customary Uses of Wildlife}

Wildlife has always been a valuable resource for the African society both in its traditional setting and in its modern form that has been influenced by western traditional values as a result of colonialism, modern lifestyles as well as religious transformation from traditional African religions to Islam, Christianity and other present day religions. While wildlife has some conventional and universal uses to society, there are some uses that are anthropologically unique to the African traditional way of life and therefore warrant special consideration. Such uses, for instance, manifest the inextricable attachment of the African peoples to the continent's wildlife.

The African people have traditionally not been game-viewers, hence in Africa, the traditional customary uses of wildlife have been consumptive in nature (Sifuna, 2009). In effect, to the Africans traditionally, the intrinsic value of wildlife is no value at all, hence to them, only consumptive uses and benefits have value. For instance, while watching wildlife will excite a white tourist, it will traditionally not excite even the most adventurous traditional African, leave alone the cultural jingoist. This is 
because traditional African culture seems to prefer consumptive benefits as opposed to intrinsic benefits. These traditional African uses of wildlife are of three main categories, namely: socio-cultural uses, nutritional uses and uses in folk medicine. These are discussed in detail in the part below.

\section{Socio-Cultural Uses}

Wildlife in Kenya and Botswana has numerous socio-cultural values and traditional uses, and is part of the socio-cultural life of many ethnic communities in these countries. Notably, some wild animals as discussed below are so revered in some communities that their totemic (sacred), ritualistic and symbolic values are enhanced through a combination of songs, dances, mythology, artistic drawings, paintings, sculpture, carvings, as well as religion. Virtually all ethnic communities in both countries have a long-standing historical association with wildlife and traditionally have some cultural attachment to certain wild animals (Ipara, 2004). This is manifested in many traditional folklore and folktales over the years. Ipara cites, for instance, folklore and folktales about "the cunning hare", "the beautiful guinea fowl", "the slow tortoise", "the mighty lion", "the stealthily leopard" and the "majestic elephant." The proverbial use of wild animals in songs and stories acts as a reservoir for society's knowledge on wildlife, enhances the stylistic attributes of folklore and folktales, and in some cases symbolizes the cultural significance of certain animals in the community concerned as will be discussed below.

Besides, some wild animals are totems in certain communities, where they are perceived to be sacred. Totemism is "the designation of a particular animal as a sacred emblem, not to be interfered with" (Kameri-Mbote, 2002). There are communities in Africa which believe that the spirits of their dead members reside in certain animal species. These species are "emblem” or totem for such communities and cannot be killed except for cultural rites or in defence against an attack by it, in the belief that a misfortune could befall the killer or his family (Ipara Ibid, Sifuna 2009). Research for this study established that to this day there are tribes in Kenya and Botswana with their own tribal totem animals. In Botswana, it was evident among four tribes namely, the BaKwena tribe (the crocodile), among the BaFurushe tribe (the baboon), among the BaRolong tribe (the wildebeest), and among the Bakgatla tribe (the monkey) (Tsiako, 2004). In Kenya, there are many tribes having tribal totem animals, for instance the Kikuyu of central Kenya; the Meru, Akamba and Embu of Eastern Kenya; the Abagusii, Abakuria, Abaluhya, Luo and Ateso of western Kenya; the Taita, Mijikenda and Pokomo of the Kenyan Coast; the Kalenjin, Turkana and Maasai of the Rift Valley region. Some of the totemic wild animals include the leopard, monkey, fox, antelope, elephant, buffalo, crocodile, tortoise and certain species of snakes for instance the cobra, puff adder and python (Sifuna, 2009).

Some animals are believed, among certain communities, to be a source of magical powers and/or strength, which powers whether real or perceived make such animals to be of remarkable socio-cultural significance in the concerned communities. It is, for instance, believed in certain communities that "association between humans and wildlife believed to be mighty, powerful and full of strength would in turn instill similar values and attributes in such humans" (Ipara, 2004). Animals such as the lion and leopard are in some communities still held as royal. There are communities in Kenya where wild animals are also used for worship and to appease the ancestral spirits. In those communities there are people who turn to wildlife worship for spiritual nourishment as others go to church for the same reason. Besides, in many communities in both Kenya and Botswana, people have names adapted from certain animals considered to be totemic or royal (Kasere, 1996). In Botswana, these names include Ndlovu (elephant), Dube (Zebra), Nyati (Buffalo), and Lakwena (Crocodile) (Sifuna, 2009). In Kenya, the names include Simba (Lion), Kwach (Leopard), Nyang or Kwena (Crocodile), Wakhisi (Antelope), Ngari (Leopard), Ndwiga (Giraffe), Nguyo (Monkey), Mosonik (Baboon), Ngatia (Lion) and Njogu (Elephant) (Sifuna, Ibid). Incidentally all these names are male names, it would be good for there to be a study seeking to establish the reason why women are not given names of wild animals yet there are female wild animals.

In both countries wildlife and wildlife resources have several traditional uses. The hides of buffalos and giraffes, for instance, are used for making shields while that of the eland is used for making belts and ropes. In both countries also, body parts of certain wild animals are used for making clothing as well as traditional ceremonial regalia. The Basarwa of Botswana use the skins of monkey and antelopes to make clothing and bedding; and hippo skin for making lashes and ropes. In Botswana, certain rare species of wildlife provided clothing of traditional chiefs and kings. In Kenya, Maasai morans still wear the lion's mane as a head dress in ceremonies. The Samburu of Kenya use antelope horns to make tobacco containers. Some animals are part of traditional passage rites in certain indigenous communities, for instance the Maasai of Kenya. Among the Maasai, an important part of the rite of passage for young adult men or "morans" (meaning a Maasai warrior) is the killing of a lion as a demonstration of bravery (Kameri-Mbote, 2002). In the course of an informal discussion with Mzee Ole Kipury a Maasai elder, this author established that the "moran" is expected to return home with the head of the lion as a symbol of bravery. On a lighter note, the said elder stated an age-old joke among the Maasai that a lion is likely to take to its heels if confronted by a "moran".

These traditional uses are increasingly being limited by the existing policies and laws in both countries and especially in Kenya where wildlife conservation is almost exclusively in the hands of the state, with the local communities having little or no say in its management. Colchester says that alienating wildlife to the state annuls, limits and restricts traditional user rights such as hunting (Cholchester, 1997). The national park status for instance, usually extinguishes traditional user rights thereby divesting local communities the true ownership of indigenous resources and illegalizing any utilization activities by them. A typical example is the Kenya government's legal ban on hunting and all forms of consumptive use of wildlife, and retained viewing and photography as the only lawful use of wildlife resources in Kenya. This ban has, for example, made it impractical to lawfully procure body parts of wild animals for traditional uses. There is however, a variance between the law and practice in that there are communities in Kenya which still utilize or kill wild animals for cultural purposes, for instance the Maasai.

Another factor that has relegated traditional African wildlife uses to the backyard is the modern way of life that has introduced foreign ideologies, conservation practices, lifestyles and religions such as Christianity. A UN report observes that most of these foreign religions for instance 'condemn African tradi- 
tional religions which, hitherto, acted to maintain an ecological balance due to the society's beliefs that their gods either were the living species or at least they were manifest in these species in a special way' (UNEP et al., 1999). As a result many indigenous communities continue to loose cultural and traditional user rights they have enjoyed over wildlife such as domestication and hunting. As traditional methods of wildlife utilization continue to be overtaken by modern methods, restricted or even extinguished by the law. In both countries, many traditional practices and taboos continue loosing their role in the use of wildlife, while tribal leaders continue loosing a say in wildlife conservation and management. The situation is worse in Kenya where wildlife management is almost exclusively a state affair. In Botswana, the situation is not as critical because it seems to be mitigated by the existence of a community-based conservation system in which the local people are routinely consulted and allowed to participate in wildlife management, utilization as well as revenue and benefit-sharing.

\section{Nutritional Uses}

Wild animals have for long been an important source of food in many societies in the world, including Kenya and Botswana where traditionally, many local communities in both countries have from time immemorial relied on wild animals for food. However not all wild animals are edible or eaten. Only edible wild animals are eaten, and only in certain communities. During the "hunting and gathering" phase of human life for instance, wildlife was a principal component of human diet as communities relied exclusively on game meat and wild plants for their nutritional requirements (Dasman, 1964). Such communities were classified as "hunter-gatherer" and they obtained their food by hunting wild animals and game birds as well as collecting the honey of wild bees, wild fruits and edible roots. In many countries around the world including Kenya and Botswana there are pockets of traditional communities that depend primarily on game meat and wild plants for foods. These communities are considered remnants of those classified as "huntergatherers" who rely on hunting for meat and gathering fruits for survival. These twentieth century hunter-gatherers are not only remnants of prehistoric ages but pursue this form of life as an adaptation to be able to exploit their rather hostile habitats.

Notably, their diet is basically determined by their habitats. Examples of these peoples are the Ogiek (Ndorobo or Dorobo) of Mau Forest in Kenya and the San (Basarwa) of the Kalahari Desert in Botswana. Coincidentally, both the names "Ogiek" and "Basarwa" in the local dialects mean "those who do not have cattle or those who do not farm. The names "Ndorobo" and "Dorobo" for instance, are a corruption of a Maasai term "Torobo" meaning the poor folk who do not have cattle. Plog et al. report that "humans and their immediate ancestors have lived on earth for about 4 million years, and for more than 99 percent of their time they grew no food of their own. Instead, they lived by hunting game animals and gathering of wild plants that grew wild in their habitats, as well as harvesting the honey of wild bees" (Plog et al., 1980).

In traditional societies, especially among the hunter-gatherer peoples, game meat was a major source of food and wild animals played a significant role in nutrition by providing humans with the body's nutritional requirements, especially protein. Meat contains about 25 percent protein, as well as minerals, vitamins and fat (Caldecott, 1988). King and Burgess report that meat is a source of complete protein, iron, zinc, vitamins and fat (King \& Burgess, 2000). Besides, meat is perhaps the most popular of all animal products worldwide (Chardonnet et al., 2002). As for game meat it "is generally higher in protein and nutritional value than meat from domestic stock, which gives game meat a higher nutritional advantage over domestic meat" (Shaw, 1985). Hakimzumwami cites Central Africa where he says people favour game meat to domestic meat claiming that it has a better taste than the latter (Hakimzumwami, 2000). The word "game meat" is used to refer to meat from wild animals. It is also sometimes referred to as "wild meat" or "bush meat." Indeed game meat can therefore be vital for the nutritional requirements of the rural people because of its role as a continuous supplement to livestock protein (Caldecott, supra). Besides, game meat, especially from culled and shot problem animals, can act a cushion against the negative values of wildlife for the rural population who comprise the bulk of the people seriously afflicted by wildlife depredation and predation. If properly managed, wild lands can yield a large crop of game meat as well as numerous ancillary animal and plant products. It is estimated that wild game can produce more meat than can domestic stock using the same area (Dasman, supra).

Moreover, today game meat is still a delicacy in many hotels in both countries the main species on the menu being eland, impala, and crocodile (Plog et al.). In third world economies such as Kenya and Botswana which because of low per capita income and rising levels of poverty are characterized by food insecurity, famine, starvation and malnutrition, wildlife can play an important role in alleviating the food problem. It is only that in the modern society the dependence of humans on game animals for food unlike that of their ancestors has progressively been reducing as dependence on domestic animals increased. Omondi 1994 reports that "there has always been an interest especially by the Food and Agriculture Organization (FAO) in the potential of game meat as a viable source of food for Africa's fast-growing population.” While it may be important for Africa to exploit this potential, precautions should be taken to ensure that any such exploitation is kept within the limits of sustainability.

\section{Uses in Folk Medicine}

Apart from the nutritional aspects of health, some wild animals are of medicinal value with their body parts being used in the cure of diseases and the manufacture of drugs. Besides, many people in most rural areas in Kenya and Botswana rely on traditional medicine for their health care. Krunk notes that several wild animals are popular for their supposed medicinal properties, with parts of some of them being used either in witchcraft or traditional medicine (Krunk, 2002). Wildlife in Kenya and Botswana has medical values in that parts of some wild animals are used for witchcraft, folk-medicine, and even modern medicine. In both countries certain wild animals, for instance crocodile and rhinoceros, are popular for their supposed medicinal properties. Among the Yeyi of Botswana, burned ash of the rhino horn is sniffed to arrest nose-bleeding, while crushed powder of the horn mixed with milk is swallowed as a cure for asthma. In Kenya, rhino horn is exported to Asia for use as an aphrodisiac while crocodile body fat is applied on the body to cure skin ailments.

In the Luhya community of western Kenya, meat of the pri- 
vate parts of a female crocodile cooked with any food is used as a love portion for adulterous husbands. Gladys Mbone a housewife in Nanyuki town of Kenya interviewed by this author during research for this work revealed that women among the Luhya communities of western Kenya cook the private parts of a female crocodile together with food and serve it to their husbands. She claims that after a husband has eaten this concoction he will never admire any other woman apart from his wife. Pharmaceutical companies could consider the use of crocodile meat as a cure for adulterous behaviour generally. Notably, the use of crocodile meat as a cure for adulterous behaviour among men is worth investigating and could be the subject of an independent research all together. Perhaps the most interesting revelation during the author's fieldwork for this paper was the use of the lion's body fat among the Samburu people of Kenya to keep away their creditors as it is believed that the scent evokes an aura of fear. Worth noting also in both countries is the use of the elephant's urine to cure asthma, and its semen to cure impotence among the old men.

The other traditional use of wildlife parts in Botswana is the use of the Bushbaby by traditional healers. Notably, 32 percent of the traditional healers interviewed by this author mentioned the animal. In an area believed to have sorcerers, the dried skin of the Bushbaby is burnt near a child and the child made to inhale the smoke. The smoke is believed to give protection to the child against the evil powers of the sorcerers. A portion of its dried meat cooked together with certain herbs and the soup are given to an epileptic to drink over a prescribed period as a cure for epilepsy. The therapeutic value of such animals in folk me- dicine is especially important in Africa where most people can not afford medicine manufactured by pharmaceutical companies due to their high prices as compared to amounts charged by traditional healers.

Research for this study revealed that traditional African customary uses of wildlife are currently threatened and seriously undermined by the modern way of life as well as government policies and the laws. This has generally resulted in local communities developing negative public attitudes towards wildlife which they now perceive as a liability instead of a resource. In many local communities, especially in Kenya, the people no longer see the importance of wildlife. With this kind of perceptions the people are unlikely to support conservation. Indeed for any conservation strategy to succeed, it requires the support of the local communities because these are the people who interact with wildlife on a daily basis and also the ones who bear the burden of wildlife predation and depredation as well as competition for scarce resources such as land, water, pastures, and fiscal resources.

\section{Modern Uses of Wildlife in Present Day Africa}

The traditional customary uses of wildlife in the present Africa not only continue to be overtaken by modern values as influenced by western values and foreign religions, but in many countries, including Kenya and Botswana, have also been and continue to be remarkably undermined by the existing policies and laws. The part below examines these modern uses of wildlife.

\section{Recreational Uses}

The recreational value of wildlife takes many different forms, and arises in terms of the pleasure that humans derive from non-consumptive wildlife utilization schemes (Green, 1992). Wildlife has intrinsic beauty and is a source of recreation for humans, with several wildlife-related recreation activities, especially aesthetic uses due to its aesthetic appeal (Giles, 1978). Mungatana 1992, has identified game viewing, photography and sport hunting as the major wildlife-related recreation activities. For his part, however, Allen notes that "the greatest significance of wild living things is aesthetic or environmental rather than exploitative" (Allen,1978). Be that as it may, the recreational values of wildlife are an important source of pleasure and enjoyment for society and are as important as the other consumptive uses discussed above. Indeed many tourists visiting Kenya and Botswana come just to watch wild animals and take pictures of the abundant wildlife treasure (See e.g GOB, 2005). Wildlife tourism is as a result of the aesthetic appeal of wildlife as tourists come for the purpose of viewing and photographing wild flora and fauna in their natural environment, and for sport hunting where permitted.

Notably, while sport hunting is allowed in Botswana, in Kenya, the Government in 1977 slapped a general ban on hunting and all forms of consumptive utilization of wildlife (KWS, 1990). The ban remains in force to date despite the promulgation of the New Constitution of 2010, which in its Preamble asserts, inter alia, the Kenyan people's pride in their ethnic, cultural and religious diversity. It also states in Article 69 that the environment and natural resources shall be utilized for the benefit of the people. With the said ban still in force it means that in Kenya unlike in Botswana, the only permitted wildlife uses are through photography and game viewing. In Botswana, sport hunting accounts for a large portion of the country's wildlife earnings. Lindsey 2010 reports that $81 \%$ of community land for wildlife production is dependent on returns from consumptive wildlife utilization. It is further estimated that trophy hunting alone generates not less than 20 Million USD annually in Botswana and more than 1000 jobs; with 6.7 Million USD generated from trophy fees alone. Even where consumptive uses are not permitted, as in the case of Kenya, wildlife is still a worthy resource in simply being there. Dasman 1964, for instance, notes: "[Even] if wildlife had no other value and were an economic detriment, it would still be worth preserving for its sheer beauty and appeal to the human spirit. Societies that spend great sums to preserve historical monuments, works of art, or scenic vistas also must be willing to preserve wildlife for its historic, artistic, and scenic merit.”

\section{Educational and Scientific Uses}

These values are those that add to human knowledge, either collectively or through research or individually through personal learning (Steinhoff, 1980). Wildlife has numerous educational values in terms of study and research. In terms of study, for instance, there is wildlife education as a distinct branch of study with its own curriculum and teachers. Both Kenya and Botswana have wildlife colleges and departments of wildlife in their institutions of higher learning. In Kenya, there is the Kenya Wildlife Service (KWS) Institute in Naivasha as well as departments of wildlife and range management in three of the public universities. There is also the KWS Field Training School at Manyani in Taita-Taveta County. While the Institute offers professional courses in wildlife-related courses, the Field Training School offers paramilitary training for those involved 
in wildlife protection. The paramilitary training is intended to equip them with skills necessary in dealing with perpetrators of illegal off-take or consumptive use of wildlife, otherwise known as poachers. Botswana has the Botswana Wildlife training Institute and a department of environmental studies at the University of Botswana, Today both countries have several scholars with $\mathrm{PhD}$ qualifications having earned their degrees from wildlife studies. Visits to wildlife educational centers by schools and adult groups for learning are another important form education. Both countries have various wildlife educational centers. Some of the leading centers in Kenya include the Wildlife Clubs of Kenya in Nairobi, William Holden Wildlife Educational Center in Mt. Kenya, and Mpala Wildlife Center in Laikipia. In Botswana they include the Maun Wildlife Educational Park and Francistown Educational Park. Such centers play an important role in public education and training in the field of wildlife.

Wild animals are also useful for research in that most researchers use them as specimens for carrying out tests. Dasman 1964 further reports that most advances in biological and medical research have come through the studies of wild or former wild species of animals, and cites the example of studies on rhesus monkeys which he says have revealed new facts about human blood chemistry and the prevention of disease. Besides, most experiments on new medicines and vaccines are tested on wild animals (Sifuna, 2006). Semen from wild animals is for instance used in research in genetics, reproductive health as well as developing vaccines and drugs for certain ailments.

\section{Uses in Modern Medicine}

Wildlife not only contributes to traditional medicine but modern medicine as well, with some of their extracts being used by pharmaceutical companies as raw material for the manufacture of drugs (Sifuna, 2006). It is estimated that over 40 percent of all prescriptions in the US for instance, contain one or more drugs that originate from wild species (UNEP, 1995). Some species may also be used in medical research.

\section{The Future of Traditional Customary Uses of Wildlife in Present Day Africa}

As already noted in this paper, before the introduction of western laws and policies by the colonialists into Africa, the indigenous communities had their own customary laws and practices on wildlife as well as traditional African wildlife values and uses. There were also traditional customary norms and practices that ensured wildlife including many problematic species co-existed with humans without much threat to each other, for instance those norms and practices that totemized certain animals or regulated their off-take. The introduction of foreign concepts relegated these traditional practices and traditional wildlife values and uses to the backyard. Besides, wildlife laws in most of Africa including Kenya and Botswana are generally still insensitive to traditional African cultural practices.

Most government programmes and policies in modern Africa are insensitive to the cultural values of the people. The neglect for traditional customary values is well summarized by Miller 1982, in the following poetic words when commenting on the Kenyan scenario: "The historic tragedy in Kenya is not the slaughter of so many animals...Most of the species could still rebuild their numbers. The tragedy is that African interests, particularly farmers, were not taken into account when formulating policies [and laws] governing wildlife management. Herein lies the seed of wildlife destruction”. Besides, wildlife laws in most of Africa including Kenya and Botswana are generally insensitive to traditional African cultural practices. For instance, while the Maasai in their culture have to kill lions as part of their rite of passage, there is no mention in the law of such practices.

In developing countries especially in the rural African context such as Kenya's and Botswana's, wildlife conservation should be understood in terms of alleviating poverty and helping the people to meet their basic needs. In developed countries it is usually perceived in terms of wildlife's aesthetic value. This is because while developed countries due to their comparatively higher incomes per capita and associated affluence require wildlife for its natural beauty and recreation and not for their survival as it is the case in developing countries. Akama 1995, observes that developing countries are preoccupied with alleviating social-economic problems arising from underdevelopment and poverty "as manifested in increasing poverty levels among the rural populations, landlessness, famine, starvation and malnutrition, and lack of clean water for domestic use.”

An examination of the traditional African customary uses of wildlife show that they are consumptive in nature and largely geared towards meeting the basic needs of humankind such as food, health and clothing. In the sense that they enable humans to derive direct benefits from the wildlife, they, for instance, manifest the inextricable attachment of the African peoples to the continent's wildlife. There is need therefore for African governments, through their policies and laws, to recognize and promote these traditional uses of wildlife. This is one way of ensuring that wildlife contributes to the day to day life of the people. It is only when this is achieved that the people of this needy continent of Africa will begin to appreciate the value of wildlife as a valuable resource to the present and future generations.

The present laws and policies in modern day Africa with regard to permitted uses of wildlife are generally undesirable. They are largely out of context, for being either unsuitable or irrelevant to local circumstances and for being generally unacceptable to the predominantly indigenous African local communities and their cultures. These factors have played out in most countries, are evident in both our study countries Kenya and Botswana, and particularly the former. For a law or policy to be effective for the purpose for which it was promulgated and apply smoothly, it has to be suitable and relevant to the local circumstances of the jurisdiction or locality in which it is applied and to its inhabitants (Sifuna, 2009). Laws and policies which are out of context for being either irrelevant or unsuitable seldom serve any useful purpose. Some of these laws were, for instance, imported by the colonialists and have been retained by the post-independence governments. Laws and policies of this nature are often unsuitable because they are fashioned on western concepts, values and perceptions which are inappropriate to the indigenous African circumstances.

Before the introduction of western laws and policies by the colonialists, the indigenous communities in Kenya and Botswana had their own customary laws and practices on wildlife as well as traditional African wildlife values and uses. There were also traditional customary norms and practices that ensured sustainable utilization wildlife species. There were, for instance, prohibitions on the killing of certain species. In many 
cultures there were prohibitions on the killing of pregnant animals, and even the sick or very young animals (Sifuna, 2009). Indeed there exist across Africa norms and practices that totemized certain animals or regulated their off-take (Sifuna, 2009). The introduction of foreign concepts relegated these traditional practices and traditional wildlife values and uses to the backyard.

This has dramatically influenced wildlife laws and policies in most of Africa including Kenya and Botswana; and made them remain generally still insensitive to traditional African cultural practices. Nevertheless, cultural orientation can at times be so strong as to make people resist even the edicts of law despite the presence of sanctions for violations (Sifuna \& Mogere, 2002). In Africa, most government programmes and policies have failed because of their being insensitive to the cultural values of the people. This setback is compounded by the fact that in most countries in Africa, including Kenya and Botswana, African customary law is one of the sources of law. The neglect for traditional customary values is well summarized by Miller in the following poetic words when commenting on the Kenyan scenario: "The historic tragedy in Kenya is not the slaughter of so many animals. Most of the species could still rebuild their numbers. The tragedy is that African interests, particularly farmers, were not taken into account when formulating policies [and laws] governing wildlife management. Herein lies the seed of wildlife destruction".

It is regrettable that law and policies applicable in a particular jurisdiction should be insensitive to traditional way of life of the very people to whom it is supposed to apply. Such laws and policies would usually not work well and neither would they work for the general good of the people. For instance, while the Maasai of Kenya in their culture have to kill lions as part of their rite of passage, there is no mention in the law of such practices. Yet, there is no day you see a Maasai Moran arraigned in a Kenyan court on charges of poaching. Whereas the reason is that in the Maasai context the killing of Lion by the Moran as a rite of passage is without the criminal state of mind (mens rea in legal verbiage), their non-prosecution is ironically evidence that that law is generally inapplicable or totally unacceptable to the Maasai people. For the Maasai Moran, this law exists only in books and not in reality.

Studies have established that the unacceptability of such laws and policies hamper their effectiveness and application (Sifuna, 2009). Undeniably, the public's acceptance of laws and policies, and their ability to comply with them are some of the most crucial determinants of the effectiveness of any law or policy (Bolen \& Robinson, 1995). As a fact, for conservation efforts to succeed, they require the support of the local communities. Atiyah 1993 observes that "Unless the mass of the public feels that there is some moral obligation to observe established law, then the law may come to be unenforceable”. Draconian and militaristic laws and policies, such as the ones that take away established rights, established traditions or disregard human welfare and livelihoods, fall in this category. Such laws and policies as already noted above will be unacceptable to the local communities and will therefore not operate smoothly. Admittedly, despite the ban of consumptive uses of wildlife in Kenya and the attendant legal and institutional framework, there is still illegal off-take of wildlife in ways that are not criminally intended, such as the said Maasai rite of passage for Morans.

Indeed, wildlife laws and policies fall in the province of public law hence should incorporate certain subtle public values such as participation, consultation as well as promotion of the public interest. Public law, as the name suggests, is concerned with public interest issues and public rights. Such a law should shift from theory to values in order to institutionalize certain societal values such as democracy, fairness, human rights and livelihoods. It should, for instance, attempt to strike a balance between wildlife conservation and competing human interests as well as other forms of land use, and between the different wildlife group interests such as the interests of conservationists and the state on the one part, and those of the local communities on the other part.

\section{Acknowledgements}

This paper is developed from research the author conducted in Kenya and Botswana for his doctoral work at the University of the Witwatersrand, Johannesburg South Africa. The author is grateful to his supervisor Prof Vincent Nmehielle and to his research assistants, the wildlife authorities as well as all the respondents in both countries who either responded to his questionnaires or attended the interviews and focus group discussions.

\section{REFERENCES}

Akama, J. S. (1995). Wildlife conservation in Kenya: A political-ecological analysis of Nairobi and Tsavo regions. Washington DC: African Development Foundation Research.

Allen, D. L. (1978). The enjoyment of Wildlife. In H. P. Brokaw, (Ed.), Wildlife and America, Penguin.

Atiyah, P. S. (1983). Law and modern society. Oxford: Oxford University Press.

Bolen, E. G. and Robinson, W. L. (1995). Wildlife ecology and management. Upper Saddle River: Prentice Hall.

Caldecott, J. (1988). Hunting and wildlife management in Sarawak. Gland: International Union for Conservation of Nature.

Chardonnet, P., des Clers, B., Fischer, J., Gierhold, R., Jori, F., \& Lamarque, F., (2002). The value of wildlife. Revue Scientifique et Technique, $21,15-51$.

Colchester, M. (1997). Salvaging nature: Indigenous peoples and protected areas. In K. Ghimire and M. P. Pimbert (Eds.), Social Change and conservation, Oxford: Earthscan Ltd.

Dasman, P. (1964). Wildlife biology. Hoboken: John Wiley \& Sons.

Giles, R. H. Jr. (1978). Wildlife management. San Francisco: W. H. Freeman.

Government of Botswana (2012). The official website of the Ministry of Tourism. Last checked 17 January 2012.

http://wwww.botswana-tourism.gov.bw/tourism_s/tourism.htm

Government of Botswana (2003). National Development Plan 9. Gaborone: Botswana Government Printer.

Government of Botswana (2005). Wildlife Statistics 2004. Gaborone: Botswana Government Printer.

Government of Botswana (2010). National Development Plan 10. Gaborone: Botswana Government Printer.

Government of Kenya (2012). The official website of the Ministry of Wildlife and Tourism, Last checked 17 January 2012.

http://www.tourism.go.ke/ministry.nsf/pages/facts_figures

Government of Kenya (2002). Effective environmental management for sustainable economic growth and poverty reduction. The National Development Plan 10. 2002-2008.

Government of Kenya (2007). Draft Wildlife Policy. Nairobi: Kenya Government Printer.

Green, B. (1992). Countryside conservation: The protection and management of amenity ecosystems. Crows Nest: G. Allen \& Unwin:

Hakimzumwami, E. (2000). Community wildlife management in central africa: A regional review. Evaluating Eden Series, Last checked 17 January 2012. 


\section{N. SIFUNA}

http://www.oie.int/eng/publication/rt/2101/ph.\%CHARDONNET.pdf Last checked 17 January 2012

http://www.kws.org/about/training/manyani.html Last checked 17 January 2012

http://www.sci-cites-talking-points-southern-africa-intl-webpage.Pdf> Last checked 17 January 2012

Ipara, H. (2004). Indigenous wildlife resources management systems: A study of the isukha community of western Kenya. D. Phil Thesis, Eldoret: Moi University, 2004.

Kameri-Mbote, P. (2002). Property rights and biodiversity management in Kenya. Nairobi: ACTS Press.

Kasere, S. (1996). Campfire: Zimbabwe's tradition of caring' United nations-non governmental Liason service (UN-NGLS). Voices of Africa No. 6: Sustainable Development Part 2. http//www. unsystem.org/ngls/documents.en/voices.africa/number6/vfab.08.htm

Kenya Wildlife Service (1990). A policy framework and five-year investment programme 1990/91-1995/96 Report.

King, S., \& Burgess, A. (2000). Nutrition for developing countries. Oxford: Oxford University Press.

Krunk, H. (2002). Hunter and hunted: Relationships between carnivores and people. Cambridge: Cambridge University Press.

Lindsey, P. (2010). The future of wildlife-based land uses in Botswana. Last checked 17 January 2012.

http://www.africanwildlifeconservationfund.org

Miller, N. N. (1982). Wildlife: Wild death. New York: State University of New York Press.

Mungatana, E. D. (1992). Recreational value of wildlife viewing: A case study of Lake Nakuru national park Kenya. M.Sc Thesis, Oslo City: Agricultural University of Norway.

Muriuki, J. N. (1996). Cooperation or conflict: Managing scarce resources of Africa: A case for community wildlife conservation in Kenya. New York: Mimeo.

Ojwang J. B., \& Kabeberi, J. W. (Eds.) (1998). Law and the public interest. Nairobi: Institute of Development Studies (IDS), University of Nairobi.

Omondi, P. (1994). Wildlife-human conflict in kenya: integrating wildlife conservation with human needs in the maasai mara region. D.
Phil Thesis, New York: McGill University.

Overseas Development Administration (ODA) (1996). Africa wildlife policy consultation. Final report of the consultation. London: ODA.

Plog, F., Bates, D.G., \& Acocella, J. R. (1980). Cultural anthropology. Wadsworth: HHT Prins.

Republic of Kenya (1977). The wildlife (Conservation and management) (Prohibition on Hunting of Game animals) Regulations.

Shaw, J. (1985). Introduction to wildlife. New York: McGraw-Hill Science.

Sifuna, N. (2006). Using eminent domain powers to acquire private lands for protected area wildlife conservation. Law, Environment and Development Journal, 2, 84-105.

Sifuna, N. (2009). Legal and Institutional Arrangements for Wildlife Damage in Kenya and Botswana. PhD Thesis, Johannesburg: University of the Witwatersrand.

Sifuna, N. \& S. Mogere. (2002). Enforcing public health law in africa: challenges and opportunities: The case of Kenya. Zambia Law Journal, 34, 148-159.

Steinhoff, H. W. (1980). Big game of North America: ecology and management. Mechanicsburg: Stackpole Books.

Takirambudde, P. N. (1988). The role of law in commercial and industrial expansion: The case of Botswana, Lesotho and Swaziland. Nairobi: English Press.

Tsiako, D. (2012) Of tribal totems and conservation' African conservation forums. Last checked 17 January 2012.

http:www.africanconservation.org/cgi-bin/dcforum/dcboard.cgi?az=r ead_count\&om=1853\&forum=DCForumID3

UNEP (1995). Taking action: An environmental guide for your community. Amsterdam: Rogers.

UNEP/UNDP/DUTCH (1999). Joint project on environmental law and institutions in Africa, east African sub-regional project development and harmonization of environmental laws. Report on the Development and Harmonization of the Laws Relating to Wildlife Management, Nairobi: United Nations Environment Programme.

Wantrup, S. V. C. (1952). Resource Conservation: Economics and Policies. Berkeley: University of California Press. 